7. Reprod. Fert. (1969) 18, 459-474

\title{
DISTRIBUTION OF ABO ISOHAEMAGGLUTININS AMONG FERTILE AND INFERTILE WOMEN
}

\author{
GEORGE I. SOLISH*
}

\author{
Department of Obstetrics and Gynecology, \\ State University of New York, Downstate, and \\ Department of Human Genetics, University of Michigan \\ (Received 22nd April 1968, revised 19th Fuly 1968)
}

\begin{abstract}
Summary. The frequency of occurrence and the titres of cervical mucus isoagglutinins were determined in a group of 204 infertile women and compared to those in 82 fertile women from approximately the same parent population. Cervical agglutinins were found more frequently among fertile women than among infertile women, the reverse of that which would be expected if these agglutinins were involved in the establishment of a deficiency of $\mathrm{A}$ and $\mathrm{B}$ children among ABO-incompatible matings. Data from an additional 1403 Negro, Puerto Rican and Caucasian women showed that the frequency of occurrence and the titres of cervical isoagglutinins varied with ethnic origin and ABO blood type of the subject but not with Rh, or MN blood types. Negro women had cervical agglutinins more frequently and in higher titres than Caucasian or Puerto Rican women while Puerto Rican women had the highest serum titres of isohaemagglutinins. Type $\mathrm{O}$ women of all ethnic groups have higher titres as well as more frequent occurrence of cervical agglutinins than type A or type B women of the same ethnic group. No relationship between age and the occurrence of cervical agglutinins was found but, among women who have cervical agglutinins, age does have a significant effect on the titre.

Season of the year and phase of the menstrual cycle have little or no effect on the presence of anti-A or anti-B agglutinins in the cervical secretions. If cervical agglutinins play any role in the process of fertilization it is a more complex one than previously supposed. The evidence presented here makes it unlikely that cervical haemagglutinins can, by prezygotic selection, account for the reported $25 \%$ deficit of blood type $\mathrm{A}$ and/or $\mathrm{B}$ children among ABO-incompatibly mated parents.
\end{abstract}

\section{INTRODUCTION}

A deficiency of blood type $\mathrm{A}$ and/or $\mathrm{B}$ children among $\mathrm{ABO}$-incompatible matings in which the father is type $A$ or $B$ and the mother type $O$ has been

* Career Scientist, Health Research Council of the City of New York. Present address: Department of Obstetrics and Gynecology, State University of New York, Downstate Medical Genter, 450 Clarkson Avenue, Brooklyn, New York 11203. 
reported by numerous authors (Waterhouse \& Hogben, 1947; Matsunaga, 1953, 1955; Matsunaga \& Itoh, 1953, 1958; Reepmaker, 1955; Levene \& Rosenfield, 1961). The precise magnitude of this deficit varies from study to study, but in general is considered to be $25 \%$, with a lower limit of $8 \%$ and an upper limit of $35 \%$ (Levene \& Rosenfield, 1961). This deficiency would be equivalent to a foetal death rate of approximately $8 \%$ of type $A$ and type $B$ children or about $3 \%$ of all conceptions. Selection of this magnitude undoubtedly warrants further inquiry into the forces involved and the mechanisms by which blood group diversity is maintained in populations.

Three principal mechanisms for these deficiencies have been suggested namely, (1) meiotic drive (Matsunaga \& Hiraizumi, 1962), (2) loss of fertilized zygotes (Levine, 1943; Van Loghem \& Spaander, 1948; Weiner, Wexler \& Hurst, 1949; McNeil, Warenski, Fullmer \& Trentelman, 1954; Sora, 1954; Reed \& Kelly, 1958; Haga, 1959; Wren \& Vos, 1961; Hiraizumi, 1964) or (3) sperm-selection (Gershowitz, Behrman \& Neel, 1958). The latter possibility has received indirect support from the demonstration of sperm-dimorphism with respect to the $A$ and $B$ antigens in individuals with $A O$ and $B O$ genotypes (Gullbring, 1957; Levine \& Chelano, 1961; Shahani \& Southam, 1962; Popivanov \& Vulchanov, 1962) and the occurrence of the ABO isoagglutinins in the secretions of the normal female genital tract (Gershowitz et al., 1958; Solish, Gershowitz \& Behrman, 1961). More recent work by Edwards, Ferguson \& Coombs (1964), Boettcher (1965) and Parish, Garron-Brown \& Richards (1967) denies the presence of ABO antigens on the spermatozoa of nonsecretors of $\mathrm{ABO}$ blood group substances. However, about three-quarters of populations tested are secretors (Gershowitz \& Neel, 1965). Hence spermatozoa of such males with attached $\mathrm{ABO}$ antigens could be exposed to possible selective effects of cervical haemagglutinin in $\mathrm{ABO}$-incompatible women producing these agglutinins.

The present investigation has been devoted to a comparison of the occurrence and titres of cervical isoagglutinins in a group of infertile women and a group of fertile controls. In addition, observations were made of the relationship of the presence of cervical isoagglutinins to other variables such as $A B O, R h$ and $M N$ blood types of the cervical secretion donor, her serum isoagglutinin titre, her ethnic origin, her age, season of the year and phase of the menstrual cycle in which the cervical secretion specimen was collected.

If cervical isoagglutinins are involved in the above-mentioned deficit of type A and type B children, they might be expected to occur with higher titres among infertile women, particularly among those women without established organic causes for their infertility. On the contrary, the fertile controls actually had cervical haemagglutinins more frequently and in higher titres than did the infertile women.

\section{MATERIALS AND METHODS}

\section{Description of study population}

Specimens of cervical secretions and venous blood were collected from 1689 unselected fertile and infertile women from seven different sources as shown in Table 1. Women from Kings County Hospital Family Planning Clinic, Kings 


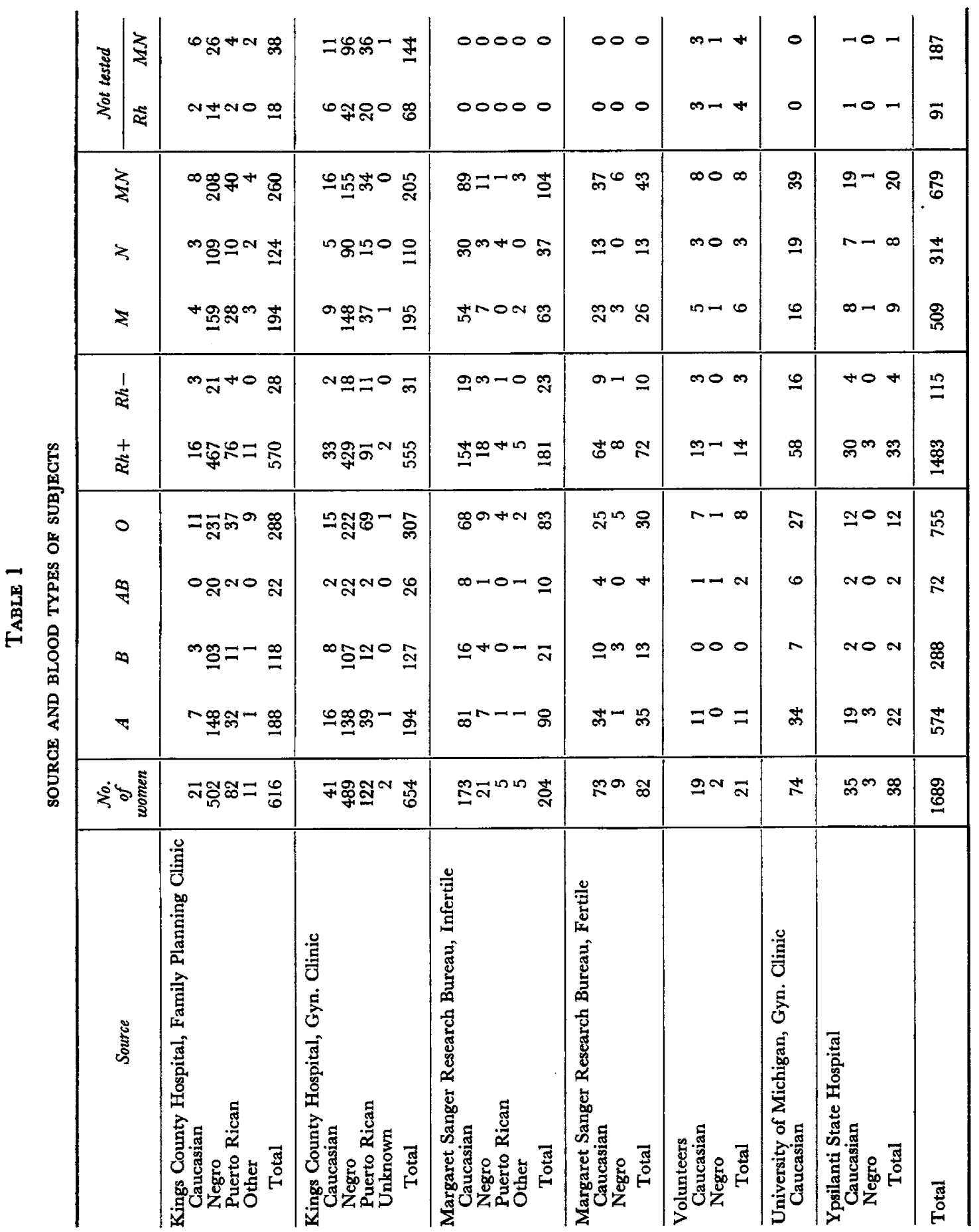


County Hospital Gynecology Clinic, Margaret Sanger Research Bureau Family Planning Clinic, Ypsilanti State Hospital and volunteers (student nurses, graduate students, office personnel and medical students' wives) are the fertile group. Patients from Margaret Sanger Research Bureau Infertility Clinic and University of Michigan Gynecology Clinic were undergoing investigation for the causes of their infertility and are the infertile women in this study. Selection was only on the basis of the willingness of these subjects to cooperate in this study.

\section{Method of collection}

Cervical secretions were obtained in most instances by aspiration directly from the cervix during the course of pelvic examination. In a few instances, cervical secretions were collected in a rubber menstrual cup by a method previously described (Solish et al., 1961). However, for the majority of specimens a specially devised polyethylene pipette attached to an aspiration pump, capable of producing a negative pressure of not more than $30 \mathrm{in.}$ of mercury, was used to collect the material under direct vision. In the laboratory, the oftengelatinous specimens obtained at a single visit, varying in amount from 0.01 to $2 \mathrm{ml}$, but usually less than $0.25 \mathrm{ml}$, were deposited from the collecting pipette into $10 \times 75 \mathrm{~mm}$ serological glass tubes by centrifugation. The tubes were corked and stored at $-10^{\circ} \mathrm{C}$.

A sample of at least $5 \mathrm{ml}$ of venous blood was also obtained from each subject contributing cervical mucus. Within $48 \mathrm{hr}$ of collection, the red cells were typed for $\mathrm{ABO}$ and $\mathrm{Rh}$ antigens by the slide technique with standard testing sera. The MN typing was performed on $2 \%$ suspensions of washed red cells in $10 \times 70 \mathrm{~mm}$ serological test tubes.

A fresh 1-ml vial of control serum prepared from outdated type $\mathrm{O}$ bank blood was thawed and titrated each day that titrations were done. The results for that day were adjusted accordingly.

Titrations of serum isoagglutinins were done with the Takatsy microtitrator (Takatsy, 1955), using test red cells prepared in $1 \%$ suspensions with phosphatebuffered saline $\left(0.45 \% \mathrm{NaCl}, 0.18 \% \mathrm{KH}_{2} \mathrm{PO}_{4}\right.$ and $\left.0.26 \% \mathrm{Na}_{2} \mathrm{HPO}_{4}\right)$. Titrations were performed by a standard doubling dilution technique.

\section{Titration of cervical secretions for isoagglutinin}

Because of the mucoid consistency and because of contamination of cervical mucus with cellular debris and foreign material from the genital tract, the following technique was devised for titration of cervical secretions. A $0 \cdot 075-\mathrm{ml}$ sample of cervical secretions was measured in a graduated micropipette, deposited in a $10 \times 70$ serology tube, and mixed with $3 \mathrm{ml}$ of buffered saline solution. Two drops of $1: 10,000$ merthiolate solution were added to this mixture, thus deliberately diluting the cervical secretion specimen forty times. After thorough mixing, the tubes with cervical secretion and saline were centrifuged at $3000 \mathrm{~g}$ at $5^{\circ} \mathrm{C}$. The supernatant, now containing the antibody, free of the cellular debris and other foreign material usually present, was divided into three equal parts. The material in the first tube was titrated for anti-A haemagglutinins; the second tube, for anti-B haemagglutinins; and the third tube served as a control. Although a large amount of saline ( $40 \mathrm{vols})$ was 
added to the reacting substances during preparation, in effect, $0.0125 \mathrm{ml}$ of cervical mucus was exposed to $0.025 \mathrm{ml}$ of red cell suspension in the first tube of the titration, resulting in a dilution of $1: 2$. In the second tube of the serial dilution $0.00625 \mathrm{ml}$ of cervical mucus was mixed with $0.025 \mathrm{ml}$ of red cell suspension resulting in a 1;4 dilution, etc. In the final analysis, therefore, the addition of forty-fold quantities of saline did not affect the proportions of reacting substances in each tube of the serial titration. The large dilution factor was used in order to extract the antibody content from the original material and transfer it, or more accurately at least 39/40ths of it, to a more suitable medium, free of mucus and debris, for easier and more precise titration than could be done with the original material. Antibody, inseparably bound to mucoprotein or mucopolysaccharide, would not be detected by this method. However, results with this method were not different from those obtained with a previously described method (Solish $e t$ al., 1961), in which reduction of viscosity of cervical mucus specimens with neuraminidase permitted testing of the whole specimen.

One-per-cent suspensions in buffered saline of type A and type B erythrocytes were used as test cells, type $\mathrm{O}$ cells were used as a control. Stock suspensions of test cells were prepared in Alsever's solution and kept no longer than 10 days at $5^{\circ} \mathrm{C}$. The cells were resuspended in buffered saline for the actual titration procedure.

The mixture of red cells and cervical secretion solution was allowed to incubate at room temperature for about $1 \mathrm{hr}$, agitating the tubes two or three times in the interim to resuspend the cells and promote better antigen-antibody contact. The tubes were then centrifuged at about $100 \mathrm{~g}$ for $30 \mathrm{sec}$ and read. The end point in titration was determined by gently dislodging the button of test red cells with a 'blow technique', using a squirt of saline diluent from a Pasteur pipette placed directly over the cell button. The dilution of the last tube in which any macroscopic agglutination occurred constituted the end point titre. Numerous repetitions of this dilution procedure with blood serum and other antibody preparations, such as commercial typing antisera and lectins gave assurance of the reproducibility of the method.

The type $\mathrm{O}$ erythrocytes served as controls for the detection of non-specific agglutination. In the few instances when cervical secretions produced nonspecific agglutination, absorption with washed, packed, type $\mathrm{O}$ red cells removed the offending substances and permitted proper titration. The forty-fold dilution method permitted absorption with minimum derangement of the volume proportions.

Testing for immune anti-A and anti-B in cervical secretions using antihuman globulin or the Witebsky neutralization technique was discontinued after trials with approximately one hundred different specimens failed to detect any significant titre differences by these methods, compared to the results obtained by the much simpler agglutination-in-saline method described above.

\section{RESULTS}

In this study, only the presence and the amount of anti-A and anti-B isohaemagglutinins were investigated. However, using goat anti-IgA, anti-IgM and anti- 


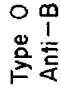

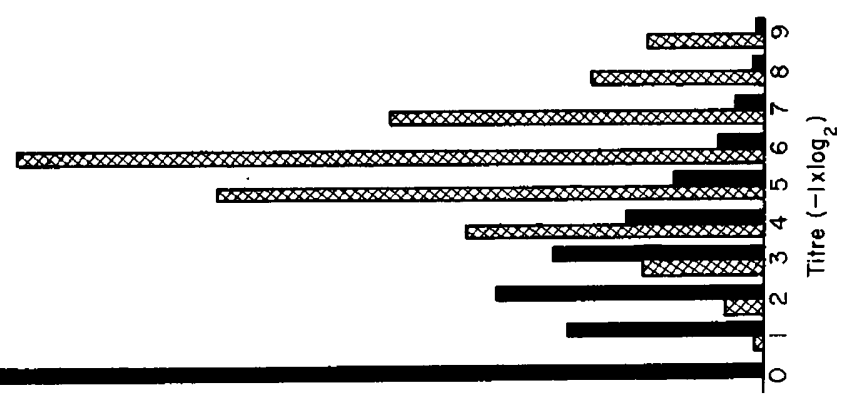
in

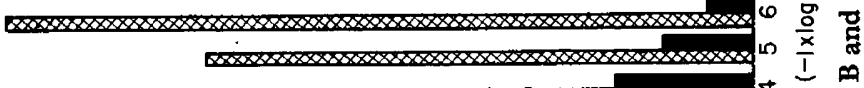

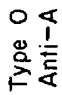

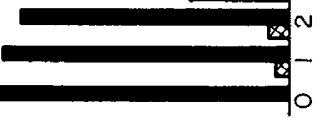

$\infty \ll$

$\stackrel{\frac{1}{2}}{2}$

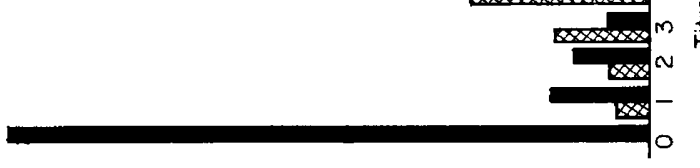

$<\infty$

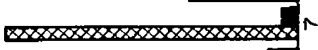

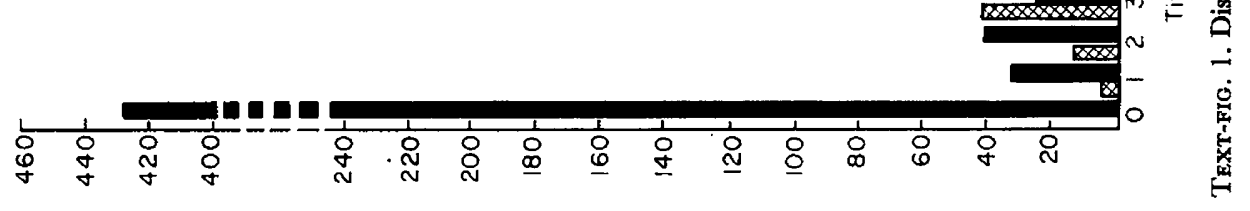


IgG antisera, at least one type of immune globulin was found in the cervical secretions of about 350 women thus far tested. The type and amount of immune globulin, present at any given time, varied with different women and in the same women under different conditions. Anti-A and anti-B isoagglutinins in the cervical secretions are probably mostly $\operatorname{IgM}$ globulins but may also be found among the IgA and IgG fractions as well. These observations form the basis of another study now in progress. The distribution of titres of isohaemagglutinating antibodies in cervical secretions for the total population studied are represented by solid lines in Text-fig. 1. The distribution of serum titres of these same women is represented by cross-hatched lines. Isoagglutinins were detected in the cervical secretions of 624 women or $39 \%$ of the 1617 women with blood types $\mathrm{A}, \mathrm{B}$ and $\mathrm{O}$ in this population. None of the seventy-two type $\mathrm{AB}$ women tested was found to have $A B O$ haemagglutinin and in no instance was a spurious cervical agglutinin inconsistent with the donor's blood type.

\section{TABLE 2}

OGGURRENGE OF CERVIGAL HAEMAGGLUTININ DURING PRE-OVULATORY, OVULATORY, AND POST-OVULATORY PHASES OF THE MENSTRUAL GYGLE AMONG COMPATIBLE TYPE O FERTILE AND INFERTILE WOMEN

\begin{tabular}{|c|c|c|c|c|}
\hline & $\begin{array}{l}\text { Pre-ovulatory } \\
\text { (Days } 4 \text { to 9) }\end{array}$ & $\begin{array}{c}\text { Ovulatory } \\
\text { (Days } 10 \text { to 19) }\end{array}$ & $\begin{array}{c}\text { Post-ovulatory } \\
(\text { Day 20+) }\end{array}$ & Total \\
\hline $\begin{array}{l}\text { No. of infertile women with cervical } \\
\text { haemagglutinin }\end{array}$ & 8 & 11 & 6 & 25 \\
\hline Total infertile women & 24 & 45 & 41 & 110 \\
\hline $\begin{array}{l}\% \text { of infertile women with cervical } \\
\text { haemagglutinin }\end{array}$ & $33 \%$ & $24 \%$ & $15 \%$ & \\
\hline $\begin{array}{l}\text { No. of fertile women with cervical } \\
\text { haemagglutinin }\end{array}$ & 107 & 107 & 152 & 366 \\
\hline Total fertile women & 182 & 197 & 266 & 645 \\
\hline $\begin{array}{l}\% \text { of fertile women with cervical } \\
\text { haemagglutinin }\end{array}$ & $59 \%$ & $54 \%$ & $57 \%$ & \\
\hline
\end{tabular}

Possible effects of other variables on the occurrence and titre of cervical isohaemagglutinins in fertile and infertile women were considered before relating the differences obtained to fertility. Either no effect was found or the data were insufficient for a definite conclusion (suggesting a small effect at best) in the following: season of the year, time of last sexual intercourse, presence of gynaecological disease, use of oral contraceptives or intra-uterine contraceptive devices, and phase of the menstrual cycle. Haemagglutinins were equally distributed among fertile pre-ovulatory, ovulatory and post-ovulatory women. Furthermore, as Table 2 shows, the proportions of fertile women in each of these three phases of the menstrual cycle were not significantly different from the proportions of infertile women in each of these categories $\left(\chi^{2}=4.92,2\right.$ d.f., $0 \cdot 2>P>0 \cdot 1$ ) but women with cervical haemagglutinin were found much more often among the fertile classes, respectively $\left(\chi^{2}=50 \cdot 03,5\right.$ d.f., $\left.P<0 \cdot 001\right)$.

$\mathrm{ABO}$ blood type, ethnic origin and age were found to have some influence on the presence of cervical isohaemagglutinins. 


\section{Blood type factors}

Cervical isohaemagglutinins were found most frequently among type $O$ women and least frequently among type A women (Table 3 ). The frequencies of occurrence of cervical isohaemagglutinins among women of type A, type $B$, and type $O$ differ markedly $\left(\chi^{2}=38.41,2\right.$ d.f., $\left.P<0 \cdot 001\right)$.

Type $\mathrm{O}$ women were more likely to have haemagglutinins in their cervical secretions than the type $A$ and type $B$ women combined $\left(\chi^{2}=36.33,1\right.$ d.f., $P<0.001)$. The anti-A and anti-B titres of type $\mathrm{O}$ women were generally higher than the anti-A titres of type B women or the anti-B titres of type A women, respectively.

The occurrence of cervical haemagglutinins appears to be unrelated to the MN blood type $\left(\chi^{2}=1.97,2\right.$ d.f., $\left.0.4>P>0.3\right)$, the $R h$ type $\left(\chi^{2}=1.27\right.$, 1 d.f., $0 \cdot 3>P>0 \cdot 2$ ) and, as previously shown, to $\mathrm{ABO}$ secretor type of the donor (Solish et al., 1961).

\section{Ethnic factors}

The frequency of occurrence of cervical haemagglutinins differed among the three ethnic groups of women shown in Table 3. The titres of these antibodies are seen in Table 4. Because they were infertility patients and their antibody titres might be thereby affected, 194 women from the Margaret Sanger Research Bureau Infertility Clinic and the sixty-eight women from the University of Michigan Gynecological Clinic, most of whom were also patients with infertility problems, were excluded from Table 3 . To avoid variations in cervical haemagglutinin titre associated with the $\mathrm{ABO}$ blood type, only type $\mathrm{O}$ women were compared. Negro women had agglutinating antibodies in their cervical secretions more frequently than did either Gaucasian $\left(\chi^{2}=5 \cdot 15,1\right.$ d.f., $0.025>P>$ $0.01)$ or Puerto Rican women $\left(\chi^{2}=4.93,1\right.$ d.f., $\left.0.5>P>0.025\right)$. Not only did these agglutinins appear more frequently, but they were found in higher titres among Negro women compared to either Caucasian or Puerto Rican women $(P<0.001$ by the Kolmogorov-Smirnov two-sample test). Differences in occurrence and titre between Caucasian and Puerto Rican groups were not significant. In addition, thirteen type $O$ Negro women had cervical anti-A, anti-B or both with titres at least two dilution tubes higher (beyond the level of technical error) than the titre of the same agglutinins in their respective sera. This phenomenon was not observed among Gaucasian or Puerto Rican women whose cervical secretion titres were almost always lower than, but occasionally equal to, their serum titres.

Age

The data for this variable are most complete for the Negro women, hence these were selected for analysis. Among type $\mathrm{O}$ Negro women, the frequencies of occurrence of anti-A cervical agglutinin among eight age classes scaled in quinquennia are not statistically different from one another $\left(\chi^{2}=8 \cdot 65,7\right.$ d.f., $0 \cdot 3>P>0 \cdot 2)$. However, if the agglutinin titres of those women who do have cervical agglutinins are compared, an age effect is detected $(F=2.42$, $7,211$ d.f., $P<0.05)$. But age effects are not apparent when titres of serum haemagglutinins of these women are compared. 


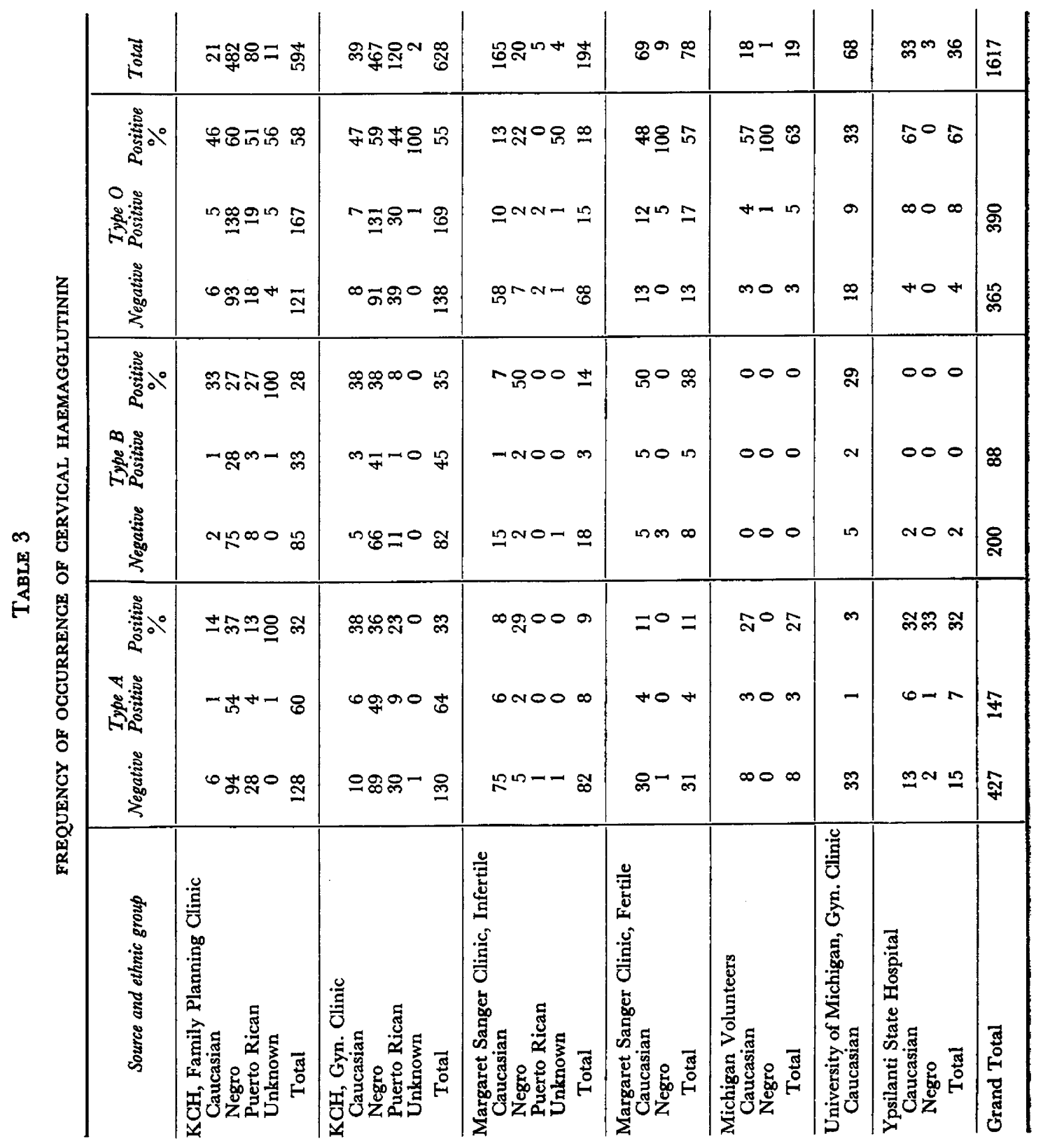




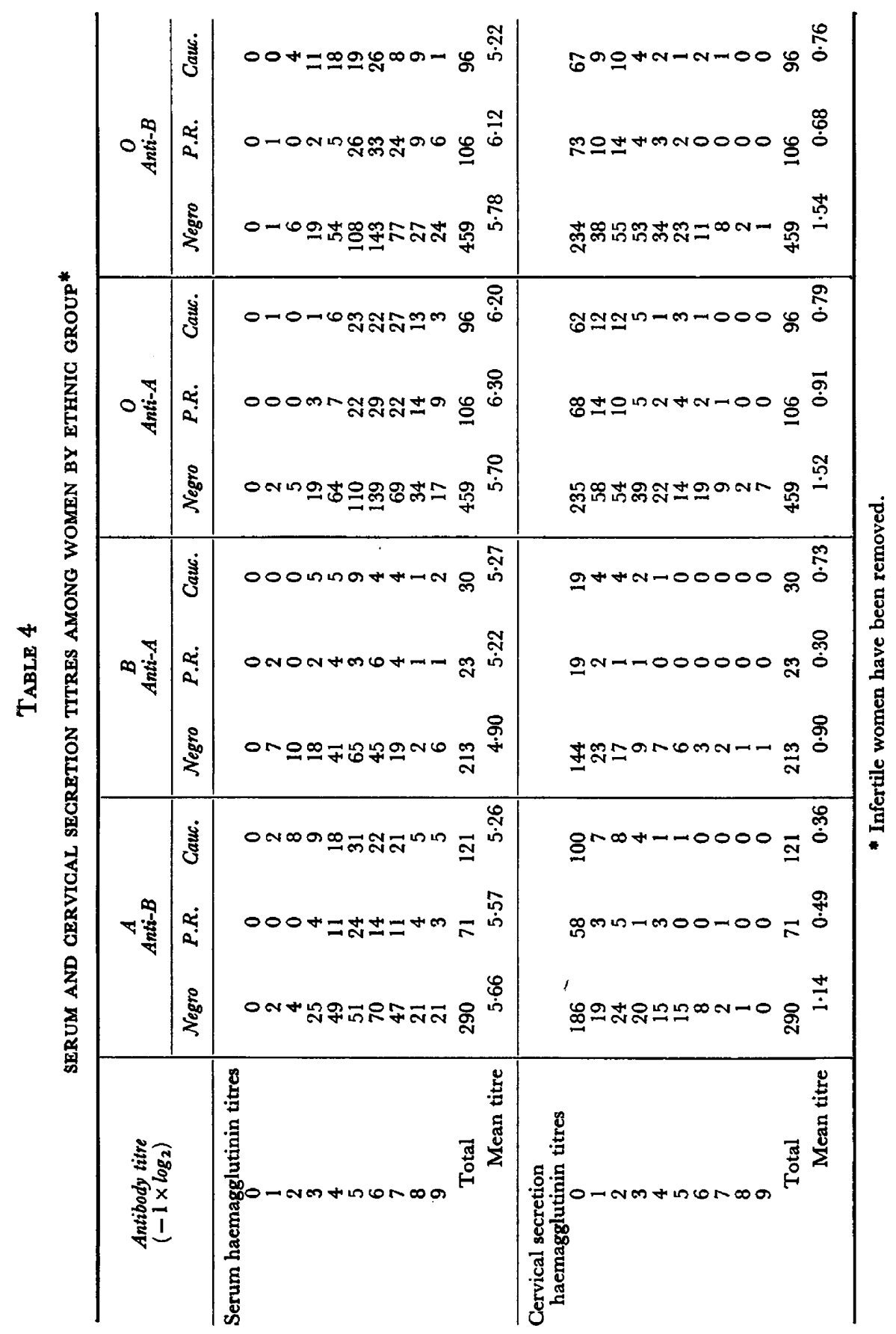




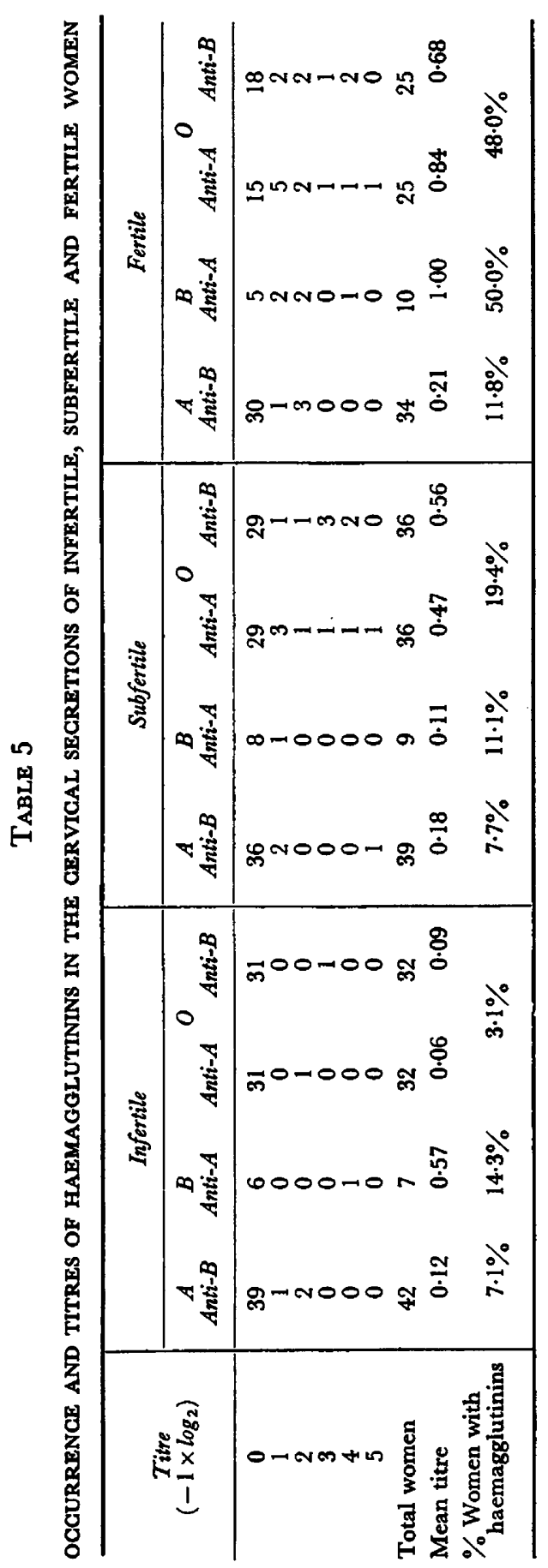


Fertility

The frequencies of occurrence and the titres of cervical haemagglutinin among 165 Gaucasian women of blood type $\mathrm{A}, \mathrm{B}$, or $\mathrm{O}$ registered in the Margaret Sanger Infertility Clinic during 1964 and 1965 were compared to those of 69 fertile Caucasian women with these blood types selected from the Margaret Sanger Family Planning Clinic for comparison (Table 5). The Infertility Clinic patients were further subdivided into two groups, subfertile and infertile, on the basis of whether pregnancy had ever occurred. Of the 165 Caucasian women, 59 have since become pregnant. An additional 25

TABLE 6

ANALYSIS OF VARIANCE AND OF COVARIANCE BETWEEN MEAN GERVICAL HAEMAGGLUTININ TITRES AND PARITY OF TYPE O NEGRO WOMEN

\begin{tabular}{l|rrrrrrrrrrr}
\hline & \multicolumn{10}{|c}{ Parity } \\
\cline { 2 - 10 } & 0 & 1 & 2 & 3 & 4 & 5 & 6 & 7 & 8 & $9+$ \\
\hline $\begin{array}{l}\text { No. of subjects } \\
\begin{array}{c}\text { Mean titres of } \\
\text { cervical anti-A } \\
\left(-1 \times \log _{2}\right)\end{array}\end{array}$ & 47 & 63 & 78 & 64 & 54 & 48 & 31 & 24 & 10 & 34 \\
\hline
\end{tabular}

\begin{tabular}{lccc}
\hline \multicolumn{4}{c}{ Analysis of variance } \\
\hline Source & Degrees of freedom & Mean squares & $F$ \\
\hline Between & 9 & $4 \cdot 483$ & $1 \cdot 046$ \\
Within & 443 & $4 \cdot 287$ & \\
Total & 452 & $8 \cdot 770$ \\
& & & \\
\hline \multicolumn{4}{c}{ Analysis of covariance* } \\
\hline Source & Degrees of freedom & Mean squares & $F$ \\
\hline Between & \multicolumn{4}{c}{5} & $5 \cdot 54245$ & $1 \cdot 33$ \\
Within & 440 & $4 \cdot 15745$ & \\
Total & 449 & $9 \cdot 69990$ & \\
\hline
\end{tabular}

* Eliminating the effects of age, serum titre, and day of cycle on which specimen was collected.

women had been pregnant at least once before clinic registration. These 84 women constitute the 'subfertile' group in Table 5. Those who never were pregnant are the 'infertile women' of Table 5. Forty-eight per cent of type $\mathrm{O}$ fertile women had cervical haemagglutinins but only $19 \cdot 4 \%$ of subfertile type $O$ women and $3.1 \%$ of infertile type $\mathrm{O}$ women had detectable cervical haemagglutinins. Fertile type $\mathrm{O}$ women, therefore, had cervical haemagglutinins significantly more often than the less fertile type $O$ women $\left(\chi^{2}=11 \cdot 24,1\right.$ d.f., $P<0.001$ ).

Of the five infertile women (three type A, one type $B$ and one type $O$ ) 
shown in Table 5 who had never been pregnant, but had haemagglutinins in their cervical secretions, three seemed to be normal but their husbands were azoospermic. Of the two remaining women in this group, one had previously had a surgical removal of one ovary and of a major portion of the other. The last patient in this group was thought to have malfunctioning oviducts. At most, then, only these last two women of the total of 81 women in the infertile group had cervical agglutinins but had never been pregnant and had husbands who were considered normal.

There are no significant differences in distribution of blood types $\mathrm{A}, \mathrm{B}$ and $\mathrm{O}$ among the three groups of women in Table $5\left(\chi^{2}=1.80,4\right.$ d.f., $\left.0.8>P>0.7\right)$.

If pregnancy stimulates haemagglutinin production, increasing titres with increasing parity might be expected. However, Table 6 shows that no significant differences in mean cervical anti-A haemagglutinin titres with increasing parity were detected among 452 blood type $O$ Negro women, divided into ten groups on the basis of the number of pregnancies experienced. An analysis of covariance (Table 6) removing possible effects due to age of the subject, phase of the menstrual cycle during which the specimen was collected and level of serum haemagglutinin fails to detect any parity effect on cervical haemagglutinin titre.

\section{DISCUSSION}

The presence of $\mathrm{ABO}$ haemagglutinating antibodies in the secretions of the lower female genital tract is now well established (Gershowitz et al., 1958; Solish et al., 1961; Tyler, Tyler \& Denny, 1967; Schwimmer, Utsay \& Behrman, 1967; Parish et al., 1967). However, the origin of these agglutinins, the mechanism of their production, their properties other than erythrocyte agglutination, and, above all, their function are still unknown. Great interest has been aroused recently by their possible relationship to infertility (Behrman, Buettner-Janush, Heglar, Gershowitz \& Tew, 1960).

Although some authors favour a systemic origin for gamma globulins found in the cervical secretions, mounting evidence supports local synthesis perhaps, as Reid (1964) has suggested, by subepithelial plasma cells producing gamma globulin beneath the cervical epithelium. Plasma cells can arise in response to the antigenic stimulation of sperm or seminal plasma antigens or both. Work by Mellors \& Korngold (1963), Straus (1961) and Parish et al. (1967) supports the notion that antibodies (presumably including isohaemagglutinins) can be produced in the local tissues in response to the proper stimulation without necessarily involving a generalized immune response. Cervical isohaemagglutinin levels, in this study, varied independently of serum isohaemagglutinin levels and, in some instances, cervical agglutinins were higher than serum agglutinins. These observations lend further support to the possibility of separate origins and rates of production for these antibodies.

The present study was designed to evaluate the role of cervical secretion isoagglutinins in the selection against A- and/or B-bearing spermatozoa, resulting in a deficiency of types $\mathrm{A}$ and/or $\mathrm{B}$ children in ABO-incompatible matings. If compensatory selection does not occur this would lead to an overall reduction in fertility. The detection of cervical haemagglutinin more frequently and in 
higher titres among fertile women compared to subfertile and infertile women however, indicates that either cervical haemagglutinins have no discernible function in prezygotic selection or that these antibodies may play an active part in the mechanism of fertilization rather than in its prevention.

Schwimmer et al. (1967), on the other hand, have reported a higher frequency of isohaemagglutinins in the cervical mucus of infertile women compared to fertile or unmarried women. The implications were that the presence of haemagglutinins in the cervical mucus has some inhibitory or cytotoxic effect on spermatozoa. Although the frequency differences are significant in this study, neither the blood types of the women nor their ethnic backgrounds are stated, factors which, the present study has shown, influence the frequency with which these antibodies occur.

Parish et al. (1967) recently reported immune anti-A in cervical mucus which proved to have no cytotoxic effects on spermatozoa carrying the A antigen. In fact, spermatozoa from a type A donor seemed to survive better in immune anti-A sera than they did in the original seminal plasma. In addition, nonspecific effects of anti-A and anti-B antisera on respiration and anaerobic glycolysis of spermatozoa were observed by Ackerman (1967). The enhancement of respiratory function and concomitant reduction in glycolysis, which he found among secretors of $\mathrm{ABO}$ blood group substance, may not necessarily result in changes in fertility since Reed, Gershowitz, Soni \& Napier (1964) and Reed (unpublished) observed no fertility differences among different secretor and non-secretor mating types. Exposure of spermatozoa to specific A or B antisera did not produce any visible adverse changes in cell motility although the specific antibody was noted to be absorbed to the sperm cell surface (Solish, unpublished). If these agglutinins had been cytotoxic, deleterious effects on motility and/or morphology of spermatozoa, similar to those observed by Parish et al. (1967) with non-agglutinating antibodies found in cervical mucus, should have been noted.

These observations taken in conjunction with the more frequent finding of cervical haemagglutinin among fertile rather than among infertile women, suggest a completely different role for these antibodies from that originally hypothesized. Absorbed haemagglutinin may, for instance, protect rather than destroy the fertilizing ability of spermatozoa. Further evidence is needed, however, to support this intriguing possibility. Although a relationship between fertility and the presence of cervical isohaemagglutinins in the secretions of the uterine cervix has been demonstrated in this investigation, the relationship is the reverse of that expected if isohaemagglutinins were to account for the prezygotic selective destruction of spermatozoa, resulting in a deficiency of $A$ and/or B children among ABO incompatible matings. Cervical isohaemagglutinins cannot therefore be considered to be major factors in the maintenance of the ABO polymorphism.

\section{ACKNOWLEDGMENTS}

This and a companion paper were submitted in partial fulfilment of the requirements for the degree of Doctor of Philosophy in the University of Michigan. 
The research reported here was supported in part by AEC Grant AT (11-1)-405 and NIH Grant HD-00617.

\section{REFERENCES}

Ackerman, D. R. (1967) Antibodies of the ABO system and the metabolism of human spermatozoa. Nature, Lond. 213, 253.

Behrman, S. J., Buettner-Janush, J., Heglar, R., Gershowitz, H. \& Tew, W. L. (1960) ABO (H) blood incompatibility as a cause of infertility: a new concept. Am. 7. Obstet. Gynec. 79, 847.

Boztrcher, B. (1965) Human ABO blood group antigens on spermatozoa from secretors and nonsecretors. F. Reprod. Fert. 9, 267.

Edwards, R. G., Ferguson, L. C. \& Coombs, R. R. A. (1964) Blood group antigens on human spermatozoa. F. Reprod. Fert. 7, 153.

Gershowitz, H., Behrman, S. J. \& NeEl, J. V. (1958) Hemagglutinins in uterine secretions. Science, N.Y. 128, 719.

Gershowrtz, H. \& NeEL, J. V. (1965) The blood groups and secretor types in five potentially fatal diseases of Caucasian children. Acta genet. Statist. med. 15, 261.

GULLBRING, B. (1957) Investigation on the occurrence of blood group antigens in spermatozoa from man, and serological demonstration of the segregation of characters. Acta med. scand. 159, 169.

HAgA, H. (1959) Studies on natural selection in ABO blood groups, with special reference to the influence of environmental changes upon the selective pressures due to maternal-fetal incompatibility. Fap. F. hum. Genet. 4, 1.

Hraizum, Y. (1964) Prezygotic selection as a factor in the maintenance of variability. Symp. quant. Biol. $29,51$.

Levene, H. \& Rosenfield, R. E. (1961) ABO incompatibility. Prog. med. Genet. 1, 120.

Levine, P. (1943) Serological factors as possible causes in spontaneous abortions. F. Hered. 34, 71.

Levine, P. \& Chelano, M. (1961) The question of $\mathrm{D}\left(\mathrm{Rh}_{\mathrm{o}}\right)$ antigenic sites on human spermatozoa. Vox Sang. 6, 720.

MAtsunaga, E. (1953) Intra-uterine selection by the ABO incompatibility of mother and foetus. Proc. Japan Acad. 29, 399.

Matsunaga, E. (1955) Intra-uterine selection by incompatibility of mother and foetus. Am. 7. hum. Genet. 7, 66.

Matsunaga, E. \& Hiraizumi, Y. (1962) Prezygotic selection in ABO blood groups. Science, N.Y. 135, 432.

MatsunagA, E. \& Iтон, S. (1953) Intra-uterine selection by the ABO incompatibility of mother and foetus. 2nd report. Proc. Fapan Acad. 29, 529.

Matsunaga, E. \& ITOH, S. (1958) Blood groups and fertility in a Japanese population with special reference to intrauterine selection due to maternal-fetal incompatibility. Ann. hum. Genet. 22, 111.

McNeil, C., Warenski, L. G., Fullmer, C. D. \& Trentelman, E. F. (1954) A study of the blood groups in habitual abortion. Am. J. clin. Path. 24, 767.

Mellors, R. C. \& Korngold, L. (1963) The cellular origin of human immunoglobulins. 7. exp. Med. $118,387$.

Parish, W. E., Carron-Brown, J. A. \& Richards, C. B. (1967) The detection of antibodies to spermatozoa and to blood group antigens in cervical mucus. F. Reprod. Fert. 13, 469.

Popivanov, R. \& Vulchanov, V. H. (1962) Segregation of man's AB group spermatozoa in A and B spermatozoa through agglutination with immune anti-A rabbit serum. Z. ImmunForsch. exp. Ther. 124, 206.

Reed, T. E., Gershowitz, H., Soni, A. \& NApier, J. (1964) A search for natural selection in six blood group systems and $\mathrm{ABH}$ secretion. Am. F. hum. Genet. 16, 161.

REED, T. E. \& KeLLY, E. L. (1958) The completed reproductive performances of 161 couples selected before marriage and classified by ABO blood group. Ann. hum. Genet. 22, 165.

ReEPMAKer, J. (1955) ABO antagonisme en morbus haemolyticus neonatorum. Stenfort Kroese, Leiden.

Reid, B. L. (1964) The behaviour of human sperm toward cultured fragments of human cervix uteri. Lancet, $\mathbf{i}, 21$.

Schwimmer, W. B., Utsay, K. A. \& Behrman, S. J. (1967) An evaluation of immunologic factors of infertility. Fert. Steril. 18, 167.

Shahant, S. \& Southam, A. L. (1962) Immunofluorescent study of the ABO blood group antigens in human spermatozoa. Am. 7. Obstet. Gynec. 84, 660.

Solish, G. I., Gershowitz, H. \& BeHRman, S. J. (1961) Occurrence and titer of isohemagglutinins in secretions of the human uterine cervix. Proc. Soc. exp. Biol. Med. 108, 645. 
SorA, P. (1954) Incompatibilita ABO tra i coniugi e aborto. Minerva ginec. 6, 80.

Straus, E. K. (1961) Occurrence of antibody in human vaginal mucus. Proc. Soc. exp. Biol. Med. 106, 617.

TAKATsY, G. Y. (1955) The use of spiral loops in serological and virological micro-methods. Acta microbiol. hung. 3, 191.

Tyler, A., Tyler, E. T. \& Denny, P. G. (1967) Concepts and experiments in immunoreproduction. Fert. Steril. 18, 153.

Van Loghem, J. J. \& SPaAnder, J. (1948) L'influence de l'incompatabilité du système ABO sur l'antagonisme Rh. Revue Hemat. 3, 276.

Waterhouse, J. A. H. \& HogBen, L. (1947) Incompatibility of mother and fetus with respect to the iso-agglutinogen $\mathrm{A}$ and its antibody. Br. F. soc. Med. 1, 1.

Weiner, A. S., WexLer, I. B. \& Hurst, J. G. (1949) The use of exchange transfusion for the treatment of severe erythroblastosis due to A-B sensitization, with observations on the pathogenesis of disease. Blood, 4, 1014.

Wren, B. G. \& Vos, G. H. (1961) Blood group incompatibility as a cause of spontaneous abortion. F. Obstet. Gynaec. Br. Commonw. 68, 637. 